DOI 10.18551/rjoas.2020-02.04

\title{
INFLUENCE OF BULL AGE ON FRESH SEMEN TRAITS OF BALI CATTLE
}

\author{
Setiawan Bayu, Nurul Isnaini* \\ Department of Animal Production, Faculty of Animal Science, University of Brawijaya, \\ Malang, Indonesia
}

Setyawan Indra Adie

Singosari National Artificial Insemination Center, Malang, Indonesia

*E-mail: nurulisna@ub.ac.id

ORCID: 0000-0002-4146-0105

\begin{abstract}
This study aimed to evaluate the influence of bull age on fresh semen traits of Bali bulls. A total of 316 semen samples collected from six Bali bulls aged at 4, 6 , and 8 years old ( 2 bulls of each age) were involved in this study. Fresh semen traits measured were semen volume, sperm concentration, total sperm, sperm motility, and total motile sperm. Data of fresh semen traits were analyzed using analysis of variance, followed by Duncan test to separate means. Additionally, data of semen volume, sperm concentration, and sperm motility were subjected to the Pearson correlation test. The result showed that the semen volume of Bali bulls increased from 4 to 6 years old $(P<0.05)$ but then tended to decrease in 8 years old bulls. However, sperm concentration remained unchanged $(P>0.05)$ among different ages. At 6 -years old, Bali bulls had the highest total sperm $(P<0.05)$, but their sperm motility was the lowest $(\mathrm{P}<0.05)$. Furthermore, the total motile sperm of Bali bulls did not differ among bull age $(P>0.05)$. Negative correlations were found between semen volume with sperm concentration $(P<0.01)$ and motility $(P<0.01)$, while a positive correlation was recorded between sperm concentration and motility $(P<0.05)$. It could be concluded that the age had an unclear pattern effect on fresh semen traits of Bali bulls at 4, 6, and 8 years old. At these ages, the Bali bulls had equal fresh semen production potency to be used in artificial insemination programs.
\end{abstract}

\section{KEY WORDS}

Artificial insemination, Bos sondaicus, Indonesian native cattle, reproductive performance, semen quality, tropical areas.

The livestock sector has a vital role in the life and development of human resources. Increasing community welfare will be followed by an increase in livestock product consumption, especially beef. The beef demand in Indonesia is increasing from year to year. Based on DGLAH (2018), the number of beef cattle population increased from 14,726,875 in 2014 to $17,050,006$ in 2018, which was followed by the increase in beef production from 497,670 tons in 2014 to 496,302 tons in 2018. East Java Province is a province with the largest cattle population of $4,657,567$ cows in 2018 or equivalent to $27.32 \%$ of the total beef cattle in Indonesia (DGLAH, 2018).

One of the Indonesian government's ongoing efforts to increase beef production is by using artificial insemination (Al) technology using frozen semen from superior males. Through the Al program, the distribution of livestock seeds can be done quickly so that it can reach farmers in various regions. Moreover, livestock populations can be increased, accompanied by an increase in genetic potential. In implementing Al, it is necessary to consider several things, namely human (farmer and inseminator), (2) physiological status of the cow, and (3) semen quality obtained from Al Center (Susilawati, 2011). The fresh semen quality can be influenced by several factors, including season, period, and age (Bhakat et al., 2011). In the previous studies, the advancing age could allow the bull to produce higher 
semen volume (Snoj et al., 2013) but with lower motility and higher abnormal spermatozoa (Brito et al., 2002).

Bali cattle (Bos sondaicus) are one of the Indonesian native meat-producing livestock and considered as national germplasm that must be conserved. Bali cattle have an advantage compared to other cattle because they have fast growth rate, easily adapt to the tropical environment, and have excellent reproductive performance. Bali cattle were mostly kept by small-scale farmers because they have good fertility and low mortality (Purwantara et al., 2012). However, until now, information about the effect of age on semen characteristics of Bali cattle is scarce. For that reason, it is necessary to evaluate the influence of bull age on fresh semen traits of Bali cattle.

\section{MATERIALS AND METHODS OF RESEARCH}

Six Bali bulls aged at 4, 6, and 8 years old ( 2 bulls of each age) belonging to the Singosari National AI Center, Malang, Indonesia, were used as experimental animals. The bulls were reared under standard management practice in the Al center.

A total of 316 semen samples (107, 70, and 139 semen samples of 4, 6, and 8 years old bulls, respectively) were involved in this study. Semen volume was measured using a scaled tube (Ratnawati et al., 2018). Sperm concentration was measured using a spectrophotometric method (Isnaini et al., 2019a). Total sperm was calculated by sperm volume x sperm concentration (Isnaini et al., 2019b). Sperm motility was measured using a light microscope (Susilawati et al., 2018). Total motile sperm was calculated by total sperm $x$ sperm motility (Isnaini et al., 2019a).

Data of fresh semen traits were analyzed using analysis of variance. Significant difference traits $(\mathrm{P}<0.05)$ were further analyzed using Duncan test to separate means. Additionally, data of semen volume, sperm concentration, and sperm motility were subjected to the Pearson correlation test.

\section{RESULTS AND DISCUSSION}

Table 1 shows the effect of bull age on fresh semen traits of Bali bulls. The semen volume of Bali bulls increased from 4 to 6 years old $(P<0.05)$ but then tended to decrease in 8 years old bulls. However, sperm concentration remained unchanged $(P>0.05)$ among different ages. At six years old, Bali bulls had the highest total sperm $(P<0.05)$, but their sperm motility was the lowest $(P<0.05)$. Furthermore, the total motile sperm of Bali bulls did not differ among bull age $(P>0.05)$.

Table 1 - Effect of bull age on fresh semen traits of Bali bulls

\begin{tabular}{ccccc}
\hline \multirow{2}{*}{ Traits } & \multicolumn{3}{c}{ Bull age } & \multirow{2}{*}{ P-value } \\
\cline { 2 - 4 } & 4 years & 6 years & 8 years & 0.011 \\
SV & $5.33 \pm 0.10^{\mathrm{a}}$ & $6.13 \pm 0.23^{\mathrm{b}}$ & $5.73 \pm 0.17^{\mathrm{ab}}$ & 0.295 \\
SC & $1.13 \pm 0.02^{\mathrm{a}}$ & $1.11 \pm 0.02^{\mathrm{a}}$ & $1.09 \pm 0.02^{\mathrm{a}}$ & 0.011 \\
TS & $6.04 \pm 0.16^{\mathrm{a}}$ & $6.77 \pm 0.27^{\mathrm{b}}$ & $5.96 \pm 0.16^{\mathrm{a}}$ & $<0.001$ \\
SM & $65.28 \pm 0.86^{\mathrm{b}}$ & $62.07 \pm 1.64^{\mathrm{a}}$ & $68.09 \pm 0.38^{\mathrm{c}}$ & 0.908 \\
TMS & $3.99 \pm 0.13^{\mathrm{a}}$ & $4.05 \pm 0.15^{\mathrm{a}}$ & $4.06 \pm 0.11^{\mathrm{a}}$ & 0.908 \\
\hline
\end{tabular}

SV: semen volume (ml/ejaculate), SC: sperm concentration (billion/ml), TS: total sperm (billion/ejaculate), SM: sperm motility (\%), TMS: total motile sperm (billion/ejaculate).

${ }^{a-c}$ uncommon superscript within the same row showed a significant difference $(p<0.05)$.

Table 2 shows the correlation among the fresh semen traits of Bali bulls. Negative correlations were found between semen volume with sperm concentration $(P<0.01)$ and motility $(P<0.01)$, while a positive correlation was found between sperm concentration and motility $(P<0.05)$.

In the present study, the increase in the semen volume of Bali bulls from 4 to 6 years probably related to the growth and development of the reproductive organ. Previously, Perumal (2014) reported that the advancing age followed by the increase in scrotal 
circumference, testes length, width, thickness, volume, and weight. Also, the advancing age related to the increase in serum testosterone concentration (Rajak et al., 2014). The increase in reproductive organs, along with the increase in testosterone concentration could increase the semen production capacity so that the semen volume could also increase.

Table 2 - Correlation among fresh semen traits of Bali bulls

\begin{tabular}{cccc}
\hline Traits & SV & SC & SM \\
\hline SV & 1 & $-0.34^{* *}$ & $-0.19^{* *}$ \\
SC & & 1 & $0.13^{*}$ \\
SM & & & 1 \\
\hline
\end{tabular}

SV: semen volume (ml/ejaculate), SC: sperm concentration (billion/ml), SM: sperm motility (\%).

*significant correlation at $P<0.05,{ }^{* *}$ significant correlation at $P<0.01$.

The high total sperm production at six years old found in this study may be due to the high semen volume at this age. However, the sperm motility at this time point was the lowest. This results probably because semen volume had a negative correlation with sperm motility. In agreement with this finding, Bhakat et al. (2011) also noted that in Sahiwal bulls, the increase in semen volume from 3.86 to $4.14 \mathrm{ml}$ followed by the reduction of sperm motility from 56.16 to $54.88 \%$.

Regardless of different age effects on semen volume and sperm motility of Bali bulls, total motile sperm probably could provide a more holistic age effect on fresh semen traits. However, the results showed that total motile sperm were equal among different age. Therefore, it could be stated that all the bull studied here had the same fresh semen production potency.

\section{CONCLUSION}

According to the results of this study, it could be concluded that the age had an unclear pattern effect on fresh semen traits of Bali bulls at 4,6 , and 8 years old. At these ages, the Bali bulls had equal fresh semen production potency to be used in artificial insemination programs.

\section{ACKNOWLEDGMENTS}

The authors acknowledge facility support from Singosari National Artificial Insemination Centre.

\section{REFERENCES}

1. Bhakat, M., Mohanty, T.K., Raina, V.S., Gupta, A.K., Khan, H.M., Mahapatra, R.K. and Sarkar, M. 2011. Effect of age and season on semen quality parameters in Sahiwal bulls. Tropical Animal Health and Production, 43(6): 1161-1168.

2. Brito, L.F.C., Silva, A.E.D.F., Rodrigues, L.H., Vieira, F.V., Deragon, L.A.G. and Kastelic, J.P. 2002. Effects of environmental factors, age and genotype on sperm production and semen quality in Bos indicus and Bos taurus Al bulls in Brazil. Animal Reproduction Science, 70(3-4): 181-190.

3. DGLAH (Directorate General of Livestock and Animal Health). 2018. Livestock and Animal Health Statistics 2018. Ministry of Agriculture Republic of Indonesia, Jakarta.

4. Isnaini, N., Wahjuningsih, S. and Adhitama, E. 2019a. Seasonal effects on semen quality of Ongole crossbred and Simmental bulls used for artificial insemination. Livestock Research for Rural Development, 31, p.16.

5. Isnaini, N., Wahjuningsih, S., Ma'ruf, A. and Witayanto, D.A. 2019. Effects of age and breed on semen quality of beef bull sires in an Indonesian artificial insemination center. Livestock Research for Rural Development, 31, p.78. 
6. Perumal, P. 2014. Scrotal circumference and its relationship with testicular growth, age, and body weight in Tho Tho (Bos indicus) bulls. International Scholarly Research Notices, 2014, p. 249537.

7. Purwantara, B., Noor, R.R., Andersson, G. and Rodriguez-Martinez, H. 2012. Banteng and Bali cattle in Indonesia: status and forecasts. Reproduction in Domestic Animals, 47(s1): 2-6.

8. Rajak, S.K., Kumaresan, A., Gaurav, M.K., Layek, S.S., Mohanty, T.K., Aslam, M.M., Tripathi, U.K., Prasad, S. and De, S. 2014. Testicular cell indices and peripheral blood testosterone concentrations in relation to age and semen quality in crossbred (Holstein Friesian× Tharparkar) bulls. Asian-Australasian Journal of Animal Sciences, 27(11): 1554-1561.

9. Ratnawati, D., Isnaini, N. and Susilawati, T. 2018. Character motility of liquid semen on Ongole crossbreed (PO), Bali and Madura bulls with different diluents at cold storage. Asian Journal of Microbiology, Biotechnology, and Environmental Sciences, 20(1): 21-28.

10. Snoj, T., Kobal, S. and Majdic, G. 2013. Effects of season, age, and breed on semen characteristics in different Bos taurus breeds in a 31-year retrospective study. Theriogenology, 79(5): 847-852.

11. Susilawati, T. 2011. Spermatology. UB Press, Malang.

12. Susilawati, T., Ratnawati, D., Isnaini, N., Kuswati and Yekti, A.P.A. 2018. Character of liquid semen motility in various diluents on Balinese cattle during cold storage. Asian Journal of Microbiology, Biotechnology, and Environmental Sciences, 20(1): 166-172. 